\title{
The Influence of Household Size on Growth Pattern of Children Aged 5-12 Years from Kazaure Emirate, Jigawa State, Nigeria
}

\author{
${ }^{*}$ Gudaji A. ${ }^{1}$, Danborno B. ${ }^{2}$ \\ ${ }^{1}$ Department of Anatomy, \\ Faculty of Basic Medical Sciences, \\ Bayero University, \\ Kano \\ ${ }^{2}$ Department of Human Anatomy, \\ Faculty of Basic Medical Sciences, \\ Ahmadu Bello University, \\ Zaria
}

Email: agudaji.ana@buk.edu.ng

\begin{abstract}
Anthropometry is the measurement of different parts of the body and is an indicator of nutritional and health status. Socio-economic variables such as income, education, birth order, family size, and urbanization are associated with the physical development of children. The aim of the study was to determine the influence of house-hold (family) size on the growth pattern of children aged 5-12 years from Kazaure emirate, Jigawa State, Nigeria. A stadiometer was used to measure height to the nearest $0.1 \mathrm{~cm}$ and weight to the nearest $0.5 \mathrm{~kg}$. A non-elastic measuring tape was used for the measurement of head, neck, chest, mid upper arm, hip, waist and calf circumferences to the nearest $0.1 \mathrm{~cm}$ respectively. A Harpenden skin fold caliper was used for the measurement of biceps and triceps skin fold thicknesses to the nearest $0.1 \mathrm{~mm}$ respectively. It was a cross-sectional survey comprising of 863 pupils of Hausa ethnic group randomly selected from public primary schools in Kazaure emirate aged 5 - 12years. Males of household size between1-2, had higher values of HT, WT and body circumferences than females except hip circumference with statistical significant difference $p<0.05$ while females had higher values of biceps and triceps skinfold thicknesses with statistical difference $p<0.05$. Males of household size $>2$, had higher values of HT, WT, BMI and body circumferences than females with statistical difference $(p<0.05)$ while females had higher values of skinfold thickness and HC with statistical difference ( $p=0.01$ ). Males of household size 1-2, had higher values of cephalofacial dimensions than females with statistical difference $(p<0.05)$ while females had higher values of nasal height and cephalic index than males with statistical difference $p<0.05$. Males of household size $>2$, had higher values of cephalofacial dimensions than females with statistical difference $p<0.05$ while females had higher values of NH and FI with statistical difference $p<0.05$. Males of household size 1-2 and $>2$, had higher values of upper and lower limbs dimensions than females with statistical difference $p<0.05$. In conclusion, it was observed that males grew better than females and, children from small family size had better growth than those from large family size.
\end{abstract}

Keywords: Age, Household-size, Growth, Kazaure emirate, Nigeria 


\section{INTRODUCTION}

Anthropometry which is defined as the measurements of different parts of the body, is widely used in surveys as an indicator of nutritional and health status (Khalid et al., 1997; Al-Sendi et al., 2003 ). The normality of human growth and development is internationally recognized as the most sensitive indicator of child health and well-being (Cameron et al., 1998). In Nigeria being one of the developing countries, the characteristic pattern of poverty, poor maternal education, high rates of morbidity, and inadequate nutritional intake of the mother and her child combine to produce a pattern of growth characterized by an increased risk of low birth weight, poor growth velocities, and a growth status that gradually falls away from the norms of children in developed countries (Cameron, 1991).

The most important criteria for healthiness and well-being of children are growth status and growth pattern. The analysis of growth patterns and the detection of aberrant growth patterns provide crucial information for the detection of pathologic condition (Kean, 2007). So growth and maturation of children are sensitive indices of health (Eiben and Panto, 1988; Tanner, 1994) and is influenced by many factors. Socio-economic state (SES) is a concept devised to measure some aspects of education, occupation, and social prestige of a person or a social group (Roche and Sun, 2003). Eiben and Mascie-Taylor (2004) observed that urban children were taller and grew faster than their rural peers. Previous studies revealed that large number of social-economic variables are associated with the physical development of children. These variables consist of parental profession, income, education (Doughlas and Simpson, 1964; Belmont et al., 1975), birth order (Eiben et al., 1996), family size (Peck and Vagero, 1987), and urbanization (Silva et al., 1985). Anthropometric characteristics have direct relationship with sex, shape and form of an individual and these factors are intimately linked with each other and are manifestation of the internal structure and tissue components which in turn, are influenced by environmental and genetic factors (Krishan, 2007).

Growth is not only accompanied by an increase in size, but also by changes in body proportions and form. The changes are especially marked during puberty and sexual dimorphism is heightened. Changes in segment lengths and breadths are useful to understand differential growth and variation in human size and proportions (Kromeyer and Jaeger, 2000).Growth is measured by measuring the height of a person, which itself is a sum of length of certain bones and appendages of the body represent certain relationship with form of proportion to the total stature (Patel et al. 2007).Height-for-age is considered to be an indicator of long-term nutritional status because an individual's present height is the result of many years' growth (WHO Working Group, 1986). Although, there is a report that, weight-for-height is frequently considered to be a better indicator of current nutritional status than is height-for-age since weight can be quickly gained or lost (Waterlow et al., 1977; WHO Working Group, 1986). Little is known about the role of individual socio-economic factors and whether socio-economic differences within countries can help in explaining the differences in children's height between countries (Drachler et al., 2002).It is well documented that children belonging to high and middle socio-economic groups are larger in body size than those in lower socio-economic groups (Goldstein, 1971; Prasad et al., 1971; Banik et al., 1972; Eleveth and Tanner, 1991).In all age groups, mean triceps and subscapular skinfold were higher in girls than in boys and they increased with age.

A similar trend was noted in the means of mid-upper arm, waist and hip circumferences (Al-Sendi et al., 2003).Similarly, in other areas of the developing world, the effects of broad socio-economic changes on growth have not been equally distributed throughout a population (Leatherman et al., 1995). It is well known that responses to modernization are 
dependent on the socio-economic characteristics of a population, including income, wealth, education, and land distribution, proximity to urban centres, population density, and changes in traditional subsistence patterns. These local factors interact with increased exposure to national and international influences, resulting in various outcomes from relative and absolute impoverishment to varying states of enrichment (McGarvey, 1992). The mechanisms through which these various factors influence growth may be mediated through the household, the basic unit for decisions and allocation of resources.

Household variables that appear important to the nutritional status of children are associated with a cash income. Children less than 5 years of age had better weight-for-age if their fathers were in paid employment and if their family lived in professionally built housing (Forsyth, 1982). Similarly, in another study, male children under 5 years of age were lighter in weight and shorter in "traditional" households as compared with "incomeearning" households (Tracer et al., 1998). In a spatial analysis of child growth, socioeconomic status as measured by family possessions was one of the most important determinants of differences in body size within populations (Mueller et al., 2001).

\section{MATERIALS AND METHODS}

\section{Materials}

The materials were used for the study were Stadiometer (Holtain Ltd., Crymych, Dyfed, UK), Non-elastic measuring tape (Seca 201 Ergonomic Circumference measuring Tape, Amazon, UK) and Harpenden skin folds Caliper (Harpenden Skin Fold Caliper, Amazon, $\mathrm{UK})$

\section{Design and Study Population}

The study design was a cross-sectional survey comprising of 863 subjects. The subjects were noted for sex and age.

The study was carried out in four (4) Local Government Areas (LGAs) of Jigawa State. Kazaure, Roni, Gwiwa and Yankwashi Local Governments Areas respectively. Of the four (4) LGA's, three towns and related primary schools were randomly selected and used for the study. 


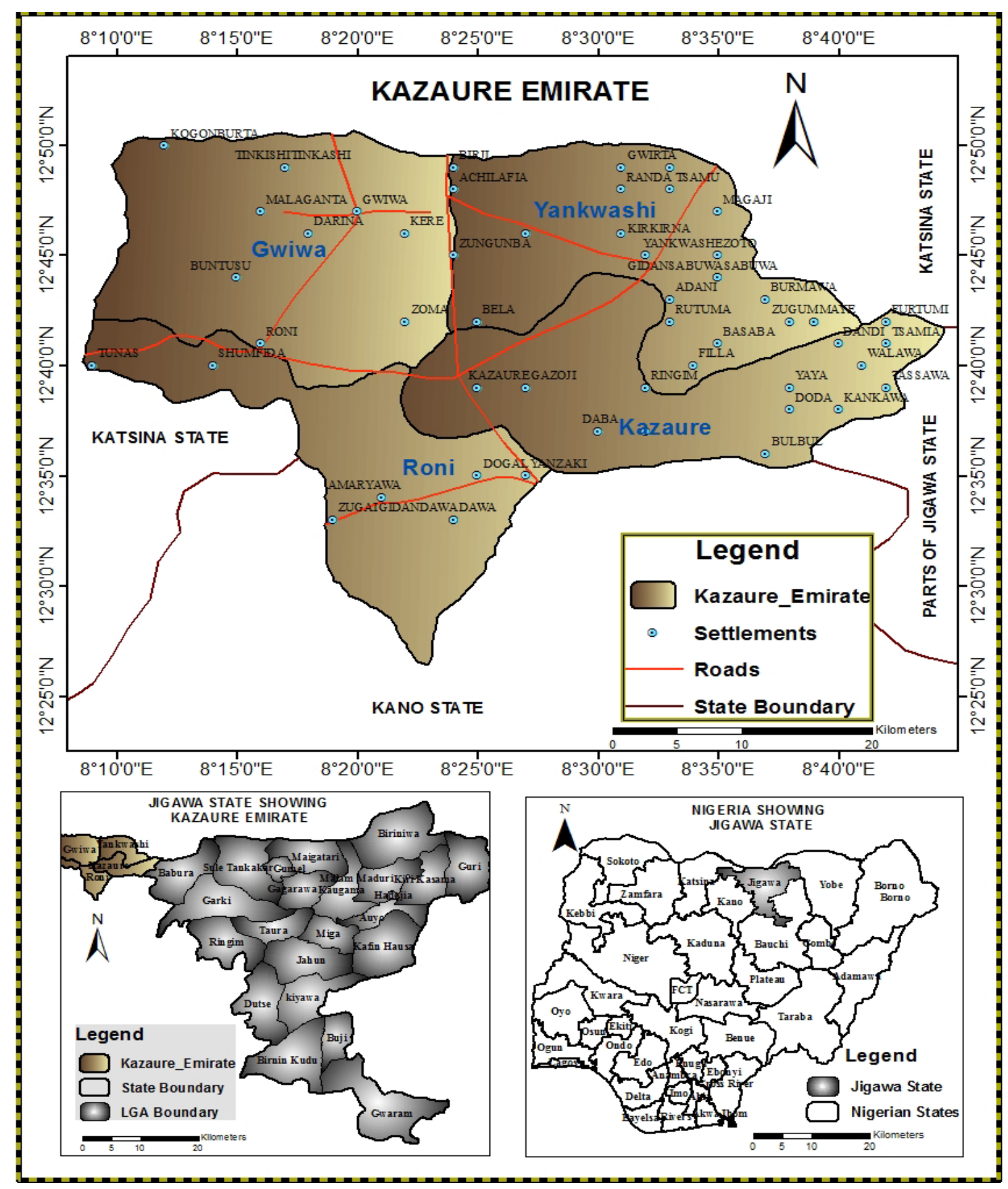

Fig.1: Map of Kazaure emirate. Modified from the Administrative Map of Nigeria

Kazaure is located in the Northern part of Jigawa State among the 27 local governments of Jigawa State. It lies between longitude $12^{\circ} 30^{\prime}$ to $12^{\circ} 45^{\prime}$ and latitude $8^{0} 15^{\prime}$ to $8^{0} 30$ North and East respectively. It covers a land area of about 1780 kilometers square. It is bordered to the north by Daura (Katsina State), West by Ingawa (Katsina State), and to the South by Dambatta (Kano state) (Olofin, 1987; Ayodele, 2000).

\section{Study Area}

Kazaure is located in the Northern part of Jigawa State, one of the 27 local governments in Jigawa State. It lies between longitude $12^{\circ} 30^{\prime}$ to $12^{\circ} 45^{\prime}$ and latitude $8^{0} 15^{\prime}$ to $8^{0} 30$ North and East respectively. It covers a land area of about 1780 kilometers square. It is bordered to the 
north by Daura (Katsina State), West by Ingawa (Katsina State), and to the South by Dambatta (Kano state) (Olofin, 1987; Ayodele, 2000). The area belongs to the Sudan Savanna Vegetation. Rainfall begins between May and June and ends around September and October. The main annual rainfall is about $600 \mathrm{~mm}$ with the highest input during the months of July and August. Mean annual temperature is about $26^{\circ} \mathrm{C}$ but mean monthly value ranges between $22^{\circ} \mathrm{C}$ in the coldest months (December and January) and $31^{\circ} \mathrm{C}$ in the hottest months of April and May (Olofin, 1987).

\section{Inclusion criteria}

Participant must be:

Public primary school pupil, between 5-12 years of age, apparently physically/mentally fit, from Kazaure Emirate and of Hausa ethnic group (parents and grandparents are Hausa).

\section{Exclusion criteria}

Participant must not be:

Private primary school pupil, below 5 years or above 12 years, of age, physically/ mentally unfit or deformed, from any Emirate other than Kazaure Emirate and of any ethnic group other than Hausa.

\section{Ethical Approval}

An ethical approval form was obtained from the ethical committee at Ahmadu Bello University Teaching Hospital. Similarly, letter of introduction was obtained and taken to Jigawa State Universal Basic Education as well as Jigawa State Ministry of Health Ethical committee for approval to conduct the research.

\section{Methods of Anthropometric Assessment}

A stadiometer was used to measure height to the nearest $0.1 \mathrm{~cm}$ and weight to the nearest $0.5 \mathrm{~kg}$, a non-elastic measuring tape was used for the measurement of head, neck, chest, mid upper arm, hip, waist and calf circumferences respectively to the nearest $0.1 \mathrm{~cm}$, a Harpenden skin fold caliper was used for the measurement of biceps and triceps skin fold thicknesses respectively to the nearest $0.1 \mathrm{~mm}$ (Lohman et al., 1988; Fidanza, 1991).

i. Height/ Stature (HT): The subjects stood up perfectly upright with arms relaxed by the side, and ankles and knees placed together. The subjects were encouraged to stand as upright as possible and bare footed before measurements were taken. The stadiometer was positioned behind the subjects and the measurement taken to the nearest $0.1 \mathrm{~cm}$.

ii. Body weight: This was taken with subjects wearing light clothes and barefooted to the nearest $0.5 \mathrm{~kg}$.

iii. Mid upper arm circumference (MUAC): This was measured using the tailor's plastic measuring tape at the midpoint of the upper non-dominant arm, between the acromial process and the tip of the olecranon and recorded to the nearest $0.1 \mathrm{~cm}$.

iv. Head/occipitofrontal circumference (HDC): This was measured using plastic tape from the occiput of the skull, to the most anterior portion of the frontal bone and recorded to the nearest $0.1 \mathrm{~cm}$.

v. Hip circumference (HC): This was measured with the subject in standing position. The tailor's plastic tape was placed on the tip of the buttock's curvature posteriorly and pubis anteriorly. The measurement was to the nearest $0.1 \mathrm{~cm}$. 
vi. Waist circumference (WC): This was taken while subject in standing position. The tape was placed between the lowest lumbar region and the sacral region posteriorly and pubic region anteriorly. The measurement was to the nearest $0.1 \mathrm{~cm}$.

vii. Calf circumference(CC): This was taken with the subject in standing position. The tape was placed on the gastrocnemius muscle posteriorly and the tibial bone anteriorly. The measurement was to the nearest $0.1 \mathrm{~cm}$.

viii. Neck circumference (NC): The tape was placed around the neck measurement recorded to the nearest $0.1 \mathrm{~cm}$.

ix. Chest circumference (CTC): The tape was placed around the chest with the tape meeting on the sternum and measurement recorded to the nearest $0.1 \mathrm{~cm}$.

$x$. Biceps skin fold thickness (BSF): This was measured on the left side using the Harpenden caliper. The measurement was to the nearest $0.1 \mathrm{~mm}$ at the upper nondominant arm anteriorly.

xi. Triceps skin fold thickness (TSF): This was measured using the Harpenden skin fold caliper at the midpoint of the upper non-dominant arm posteriorly to the nearest $0.1 \mathrm{~mm}$. All skin fold measurements were taken twice and the average recorded.

\section{Statistical Analyses}

Data were expressed as mean \pm standard deviation (SD). Differences between boys and girls were tested using the student's $t$ - test. One-way analysis of variance (followed by Benferoni Post Hoc test) was used to investigate the effect of socio-economic factor (household size) on the different anthropometric parameters. Statistical significant difference was deemed acceptable at $\mathrm{P}<0.05$. The data were analyzed using Statistical Package for Service Solutions (SPSS) version 20 (IBM Corporation, Armonk, New York, USA).

\section{RESULTS}

Results on table1: shows the descriptive statistics of male and female pupils who participated in study. The results showed the Mean $\pm S D$, minimum and maximum values of height, weight, body mass index, biceps and triceps skinfold thicknesses; mid-upper arm, head, neck, chest, waist, hip and calf circumferences of the pupils.

Results on table 2: shows the influence of household size between 1-2 on height, weight, BMI, biceps and triceps skin fold thicknesses, mid-upper arm, head, neck, chest, waist, hip and calf circumferences of male and female pupils of Kazaure emirate with the males having higher values than females. The differences were statistically significant $(p<0.05)$. On the other hand, females showed higher values than males with statistical difference $(p<0.05)$ in biceps skinfold thickness, triceps skinfold thickness, hip circumference.

The influence of household size $>2$ on height, weight, BMI, biceps and triceps skin fold thicknesses, mid-upper arm, head, neck, chest, waist, hip and calf circumferences on male and female pupils of Kazaure emirate with males having higher mean values than females with statistical difference $(\mathrm{p}<0.05)$ in height, weight, BMI, mid-upper arm circumference, head circumference, neck circumference, chest circumference, waist circumference and calf circumference. Conversely, the females showed higher values than males with statistical difference $(p=0.01)$ in biceps skinfold thickness, triceps skinfold thickness and hip circumference. 
Table 1: Descriptive statistics of male and female pupils from Kazaure emirate $(n=863)$

\begin{tabular}{lrrrr}
\hline & \multicolumn{2}{c}{ Male $(\mathrm{n}=432)$} & \multicolumn{2}{c}{ Female $(\mathrm{n}=431)$} \\
Variables & Mean \pm SD & \multicolumn{1}{c}{ Min - Max } & Mean \pm SD & \multicolumn{1}{c}{ Min-Max } \\
\hline Age $($ years $)$ & $8.56 \pm 2.27$ & $5.00-12.00$ & $8.43 \pm 2.34$ & $5.00-12.00$ \\
Height $(\mathrm{cm})$ & $124.00 \pm 14.00$ & $99.00-150.00$ & $121.00 \pm 14.00$ & $96.00-148.00$ \\
Weight $(\mathrm{kg})$ & $25.14 \pm 4.07$ & $10.90-40.30$ & $23.60 \pm 4.83$ & $13.30-37.30$ \\
Body Mass Index $\left(\mathrm{kg} / \mathrm{m}^{2}\right)$ & $15.64 \pm 1.52$ & $12.27-21.44$ & $14.24 \pm 1.41$ & $11.54-20.08$ \\
Biceps Skinfold Thickness $(\mathrm{mm})$ & $1.17 \pm 0.26$ & $1.00-2.00$ & $1.46 \pm 0.21$ & $1.00-2.54$ \\
Triceps Skinfold Thickness $(\mathrm{mm})$ & $1.12 \pm 0.33$ & $1.00-2.00$ & $1.41 \pm 0.22$ & $1.00-2.50$ \\
Mid-upper arm Circumference $(\mathrm{cm})$ & $16.80 \pm 1.39$ & $12.50-22.00$ & $15.72 \pm 1.62$ & $11.50-20.00$ \\
Head Circumference $(\mathrm{cm})$ & $50.73 \pm 2.41$ & $48.00-56.30$ & $49.26 \pm 2.67$ & $47.00-54.00$ \\
Neck Circumference $(\mathrm{cm})$ & $24.89 \pm 1.34$ & $20.50-32.50$ & $23.33 \pm 1.66$ & $19.00-30.00$ \\
Chest Circumference $(\mathrm{cm})$ & $57.62 \pm 4.37$ & $44.50-68.50$ & $55.73 \pm 4.20$ & $42.60-67.00$ \\
Waist Circumference $(\mathrm{cm})$ & $56.14 \pm 3.94$ & $46.00-69.50$ & $54.82 \pm 4.57$ & $42.50-66.00$ \\
Hip Circumference $(\mathrm{cm})$ & $59.50 \pm 5.53$ & $44.20-72.00$ & $62.80 \pm 4.94$ & $48.20-75.00$ \\
Calf Circumference $(\mathrm{cm})$ & $22.55 \pm 1.98$ & $12.80-28.00$ & $21.83 \pm 2.51$ & $12.00-27.00$ \\
& & & & \\
\hline
\end{tabular}

Table 2: Influence of household size on height, weight, BMI, skinfold thicknesses and body circumferences of pupils aged 5-12 years from Kazaure emirate

\begin{tabular}{|c|c|c|c|c|c|c|c|c|}
\hline \multirow[b]{3}{*}{ Variable } & \multicolumn{4}{|c|}{ House hold size 1-2 } & \multicolumn{4}{|c|}{ House hold size $>2$} \\
\hline & $\begin{array}{c}\text { Male } \\
(\mathrm{n}=337)\end{array}$ & $\begin{array}{l}\text { Female } \\
(n=326)\end{array}$ & & & Male $(\mathrm{n}=95)$ & $\begin{array}{l}\text { Female } \\
(n=105)\end{array}$ & & \\
\hline & Mean \pm SD & Mean \pm SD & $\mathrm{F}$ & $\begin{array}{c}\mathrm{p}- \\
\text { value }\end{array}$ & Mean \pm SD & Mean \pm SD & $\mathrm{F}$ & $\mathrm{p}$ - value \\
\hline HT (cm) & $124.45 \pm 13.30$ & $121.39 \pm 13.60$ & 2.930 & 0.001 & $120.83 \pm 13.94$ & $119.91 \pm 13.56$ & 2.463 & 0.01 \\
\hline WT (kg) & $25.33 \pm 2.21$ & $23.58 \pm 2.45$ & 3.742 & $<0.001$ & $23.45 \pm 1.85$ & $22.43 \pm 1.45$ & 2.397 & 0.01 \\
\hline $\operatorname{BMI}\left(\mathrm{kg} / \mathrm{m}^{2}\right)$ & $15.65 \pm 2.36$ & $15.24 \pm 2.55$ & 3.468 & 0.001 & $15.42 \pm 1.38$ & $14.50 \pm 1.53$ & 2.294 & 0.01 \\
\hline $\mathrm{BSF}(\mathrm{mm})$ & $1.17 \pm 0.43$ & $1.51 \pm 0.28$ & 2.019 & $<0.05$ & $1.16 \pm 0.27$ & $1.62 \pm 0.35$ & 2.104 & 0.01 \\
\hline TSF (mm) & $1.41 \pm 0.35$ & $1.60 \pm 0.22$ & 2.031 & $<0.05$ & $1.28 \pm 0.37$ & $1.54 \pm 0.39$ & 2.165 & 0.01 \\
\hline MUAC (cm) & $16.60 \pm 2.38$ & $15.72 \pm 2.64$ & 2.492 & 0.01 & $16.75 \pm 1.43$ & $15.70 \pm 1.57$ & 2.354 & 0.01 \\
\hline $\operatorname{HDC}(\mathrm{cm})$ & $50.70 \pm 3.62$ & $50.24 \pm 3.80$ & 2.207 & 0.01 & $50.85 \pm 2.41$ & $50.09 \pm 2.60$ & 1.988 & $<0.05$ \\
\hline $\mathrm{NC}(\mathrm{cm})$ & $24.89 \pm 2.30$ & $23.51 \pm 2.60$ & 3.076 & 0.001 & $24.86 \pm 1.45$ & $24.29 \pm 1.60$ & 1.962 & $<0.05$ \\
\hline CTC (cm) & $57.70 \pm 3.42$ & $55.62 \pm 3.62$ & 4.188 & $<0.001$ & $57.31 \pm 2.40$ & $55.07 \pm 2.59$ & 2.114 & 0.01 \\
\hline WC (cm) & $55.25 \pm 3.56$ & $54.75 \pm 3.75$ & 2.539 & 0.01 & $55.05 \pm 2.66$ & $54.63 \pm 2.73$ & 2.311 & 0.01 \\
\hline $\mathrm{HC}(\mathrm{cm})$ & $59.78 \pm 3.83$ & $60.04 \pm 3.52$ & 2.236 & 0.01 & $58.67 \pm 2.43$ & $59.62 \pm 2.97$ & 2.233 & 0.01 \\
\hline $\mathrm{CC}(\mathrm{cm})$ & $22.62 \pm 2.07$ & $21.81 \pm 2.51$ & 2.609 & 0.01 & $22.29 \pm 1.39$ & $21.90 \pm 1.55$ & 1.997 & $<0.05$ \\
\hline
\end{tabular}


$\mathrm{HT}=$ height, $\mathrm{WT}=$ Weight, $\mathrm{BMI}=$ Body mass index, $\mathrm{BSF}=$ Biceps skinfold thickness, $\mathrm{TSF}=$ Triceps skinfold thickness, MUAC $=$ Mid-upper arm circumference, $\mathrm{HDC}=$ Head circumference, $\mathrm{NC}=$ Neck circumference, $\mathrm{CTC}=$ Chest circumference, $\mathrm{WC}=$ Waist circumference, $\mathrm{HC}=$ Hip circumference, $\mathrm{CC}=\mathrm{Calf}$ circumferences

Results on table 3: shows the influence of household size between 1-2 on head length, head breadth, facial length, facial breadth, cephalic index, facial index, nasal height of male and female pupils of Kazaure emirate with males having higher values than females with statistical difference $(p<0.05)$ in head length, head breadth, facial length and facial breadth. Conversely, the females showed higher values than males with statistical difference $(p<0.05)$ in nasal height and cephalic index.

The influence of household size $>2$ on head length, head breadth, facial length, facial breadth, cephalic index, facial index, nasal height of male and female pupils of Kazaure emirate with males having higher values than females with statistical difference $(p<0.05)$ in head length, head breadth, facial length and facial breadth. However, the females showed higher value than males with significant difference $(p<0.05)$ in nasal height and facial index.

Results on table 4 shows the influence of household size between 1-2 on right humerus length, left humerus length, right ulna length, left ulna length, right radial length, left radial length, right hand length, left hand length, right hand breadth and left hand breadthof male and female pupils of Kazaure emirate with males having higher values than females with statistical difference $(\mathrm{p}<0.05)$ in right and left humerus length, right and left ulna length, right, left radial length, right and left hand length, right and left hand breadth.

The influence of household size $>2$ on right humerus length, left humerus length, right ulna length, left ulna length, right radial length, left radial length, right hand length, left hand length, right hand breadth and left hand breadth of male and female pupils of Kazaure emirate with males having higher mean than females with statistical difference $(p<0.05)$ in right and left humerus length, right and left ulna length, right and left radial length, right and left hand length, right and left hand breadth respectively.

Table 3: Influence of household size on craniofacial dimensions of pupils aged 5-12 years from Kazaure emirate

\begin{tabular}{|c|c|c|c|c|c|c|c|c|}
\hline \multirow[b]{2}{*}{ Variable } & \multicolumn{2}{|c|}{ House hold size 1-2 } & \multicolumn{5}{|c|}{ House hold size $>2$} & \multirow[b]{2}{*}{$\mathrm{p}$ - value } \\
\hline & $\begin{array}{l}\text { Male } \\
(\mathrm{n}=337) \\
\text { Mean } \pm S D\end{array}$ & $\begin{array}{l}\text { Female } \\
(n=326) \\
\text { Mean } \pm S D\end{array}$ & $\mathrm{~F}$ & $\begin{array}{l}\mathrm{p}- \\
\text { value }\end{array}$ & $\begin{array}{l}\text { Male } \\
(n=95) \\
\text { Mean } \pm S D\end{array}$ & $\begin{array}{l}\text { Female } \\
(n=105) \\
\text { Mean } \pm S D\end{array}$ & F & \\
\hline HDL (cm) & $17.90 \pm 1.53$ & $16.53 \pm 1.78$ & 4.949 & $<0.001$ & $17.78 \pm 1.53$ & $16.40 \pm 1.78$ & 3.138 & 0.001 \\
\hline $\mathrm{HDB}(\mathrm{cm})$ & $12.94 \pm 1.56$ & $11.85 \pm 1.64$ & 3.204 & $<0.001$ & $12.79 \pm 1.56$ & $11.71 \pm 1.64$ & 2.381 & 0.01 \\
\hline $\mathrm{FL}(\mathrm{cm})$ & $9.38 \pm 0.58$ & $8.66 \pm 0.59$ & 2.258 & 0.01 & $9.30 \pm 0.61$ & $8.54 \pm 0.59$ & 1.992 & $<0.05$ \\
\hline $\mathrm{FB}(\mathrm{cm})$ & $10.41 \pm 1.65$ & $9.62 \pm 1.66$ & 2.463 & 0.01 & $10.05 \pm 1.57$ & $9.38 \pm 1.66$ & 2.176 & 0.01 \\
\hline $\mathrm{NH}(\mathrm{cm})$ & $3.62 \pm 0.30$ & $3.84 \pm 0.34$ & 1.924 & $<0.05$ & $3.57 \pm 0.39$ & $3.80 \pm 0.37$ & 1.948 & $<0.05$ \\
\hline $\mathrm{CI}$ & $72.34 \pm 3.10$ & $72.89 \pm 3.68$ & 1.900 & $<0.05$ & $72.31 \pm 3.10$ & $72.45 \pm 3.68$ & 0.348 & 0.708 \\
\hline FI & $90.23 \pm 4.75$ & $90.51 \pm 4.76$ & 0.764 & 0.445 & $89.93 \pm 4.46$ & $90.49 \pm 4.67$ & 1.970 & $<0.05$ \\
\hline
\end{tabular}

$\mathrm{HDL}=$ head length, $\mathrm{HDB}=$ head breadth, $\mathrm{FL}=$ facial length, $\mathrm{FB}=$ facial breadth, $\mathrm{CI}=$ cephalic index, $\mathrm{FI}=$ facial index, $\mathrm{NH}=$ nasal height 
Table 4: Influence of household size on bones of upper extremities of pupils aged 5-12 years from Kazaure emirate

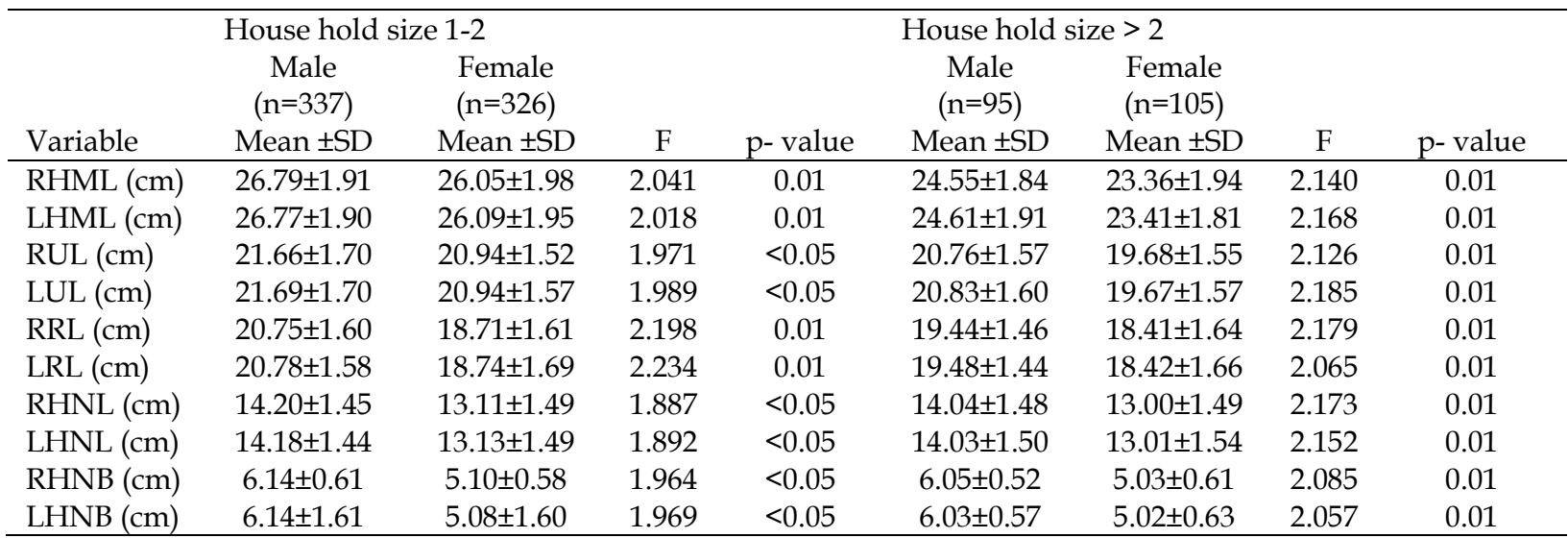

RHML=right humerus length, LHML = left humerus length, RUL= right ulna length, $\mathrm{LUL}=$ left ulna length $\mathrm{RRL}=$ right radius length, $\mathrm{LRL}=$ left radius length, $\mathrm{RHNL}=$ right hand length, $\mathrm{LHNL}=$ left hand length, $\mathrm{RHNB}=$ right hand breadth, LHNB= left hand breadth

Results on table 5 shows the influence of household size between 1-2 on right tibial length, left tibial length, right fibular length, left fibular length, right foot length, left foot length, right foot breadth and left foot breadth on male and female pupils of Kazaure emirate with males having higher values than females with statistical difference $(p<0.05)$ in right and left tibia length, right and left fibula length, right and left foot length, right and left foot breadth. The influence of household size $>2$ on right tibial length, left tibial length, right fibular length, left fibular length, right foot length, left foot length, right foot breadth and left foot breadth of male and female pupils of Kazaure emirate with males having higher values than females with significant difference $(\mathrm{p}<0.05)$ in right and left tibia length, right and left fibula length, right and left foot length, right and left foot breadth.

Table 5: Influence of household size on bones of lower extremities of pupils aged 5-12 years from Kazaure emirate

\begin{tabular}{|c|c|c|c|c|c|c|c|c|}
\hline \multirow[b]{3}{*}{ Variable } & \multicolumn{3}{|c|}{ House hold size 1-2 } & \multicolumn{4}{|c|}{ House hold size $>2$} & \multirow[b]{3}{*}{$\mathrm{p}$ - value } \\
\hline & $\begin{array}{c}\text { Male } \\
(\mathrm{n}=337)\end{array}$ & $\begin{array}{l}\text { Female } \\
(\mathrm{n}=326)\end{array}$ & & & $\begin{array}{c}\text { Male } \\
(\mathrm{n}=95)\end{array}$ & $\begin{array}{l}\text { Female } \\
(\mathrm{n}=105)\end{array}$ & & \\
\hline & Mean \pm SD & Mean \pm SD & $\mathrm{F}$ & $p$-value & Mean \pm SD & Mean \pm SD & F & \\
\hline RTBL (cm) & $29.34 \pm 1.28$ & $28.28 \pm 1.47$ & 1.897 & $<0.05$ & $29.35 \pm 3.11$ & $28.32 \pm 3.33$ & 1.897 & $<0.05$ \\
\hline LTBL $(\mathrm{cm})$ & $29.41 \pm 1.31$ & $28.34 \pm 1.46$ & 1.886 & $<0.05$ & $29.38 \pm 3.10$ & $28.35 \pm 3.29$ & 1.886 & $<0.05$ \\
\hline RFBL (cm) & $28.30 \pm 1.24$ & $27.20 \pm 1.46$ & 1.912 & 0.01 & $28.15 \pm 2.48$ & $27.12 \pm 2.65$ & 1.912 & 0.01 \\
\hline LFBL $(\mathrm{cm})$ & $28.27 \pm 1.31$ & $27.19 \pm 1.49$ & 1.908 & 0.01 & $28.20 \pm 2.01$ & $27.17 \pm 2.31$ & 1.908 & 0.01 \\
\hline RFTL (cm) & $19.76 \pm 1.25$ & $18.67 \pm 1.39$ & 1.873 & $<0.05$ & $19.43 \pm 2.28$ & $18.29 \pm 2.58$ & 1.873 & $<0.05$ \\
\hline LFTL $(\mathrm{cm})$ & $19.79 \pm 1.26$ & $18.70 \pm 1.30$ & 1.854 & $<0.05$ & $19.46 \pm 2.25$ & $18.26 \pm 2.60$ & 1.854 & $<0.05$ \\
\hline RFTB (cm) & $6.85 \pm 0.67$ & $6.21 \pm 0.77$ & 1.863 & $<0.05$ & $6.77 \pm 1.64$ & $6.10 \pm 1.73$ & 1.863 & $<0.05$ \\
\hline LFTB (cm) & $6.85 \pm 0.69$ & $6.20 \pm 0.80$ & 1.875 & $<0.05$ & $6.75 \pm 1.60$ & $6.12 \pm 1.64$ & 1.875 & $<0.05$ \\
\hline
\end{tabular}

RTBL= right tibia length, LTBL= left tibia length, RFBL= right fibula length, $\mathrm{LFBL}=$ left fibula length, RFTL= right foot length, LFTL= left foot length, RFTB= right foot breadth, LFTB= left foot breadth

\section{DISCUSSION}


The anthropometric parameters of growth examined in this study population showed that the males had higher height, weight and BMI than females. Studies by Pena Reyes et al. (2002), Donald, (2002), Al-Sendi et al. (2003) showed that males had higher height, weight and BMI than the females. Additionally, studies by Ilayperuma, (2010); Kharyal and Nath, (2008); Ezekie et al.(2015), reported that males had higher height than the females respectively. However, studies by Bolzan et al. (1999) showed that the females were found to be taller, heavier and had higher BMI than the males. This differs from the result of this study whereby the males were taller, heavier and had higher BMI. Similarly, females had higher values for biceps and triceps skin folds thicknesses than the males, and this agrees with findings by Al-Sendi et al. (2003) whereby the females had higher values for triceps and subscapular skin folds than the males at all ages (12-17 years). The males had higher values than the females in the body circumferences except hip circumference respectively This was in line with reports by Al-Sendi et al.(2003) who found that males had higher waist circumference than the females while the females had higher mid-upper arm and hip circumferences than the males. Studies by Ezekie et al. (2015) reported that Igbo males had higher head circumference than the Igbo females. Likewise, males had higher waist and neck circumferences than the females and this corroborates the findings of Mozaffer et al. (2012). This study showed that males had larger head length, head breadth, facial height and facial breadth than the females respectively. Studies by Kharyal and Nath, (2008), Olotu et al. (2009), Ilayperuma, (2010); Omotoso et al. (2011), Bugaighis et al. (2013); Ezekie et al. (2015); Shah et al. (2015); Kpela et al. (2016) showed that males had higher head length, head breadth, facial height and facial breadth than the females. These are in line with the findings of this present study. Studies by Shah et al. (2015) on assessment of cephalic and facial indices as a proof for ethnic and sexual dimorphism showed that females had higher cephalic and facial indices than the males in non-Gujurat ethnic group while in Gujurat ethnic group males had higher facial index while females had higher cephalic index. This study showed that females had higher cephalic and facial indices than the males, and therefore agrees with the findings of Shah et al. (2015). Furthermore, females showed higher nasal height than the males in this study, however, this contradicts the findings of Kharyal and Nath, (2008) who reported that males had higher nasal height than the females.

Studies by Goldstein, (1971), Prasad et al. (1971), Banik et al. (1972), Eleveth and Tanner, (1991) concluded that children belonging to higher and middle socioeconomic groups are larger in body size than those in lower socio-economic groups. Kim et al. (2002) also suggested that presumably, amenities that contribute to "quality of life" are, on average, more accessible to urban than to rural children. Studies by Rona and Chinn (1986), Berdasco (1994), Naidu and Rao (1994) showed that increase in anthropometric measurements is associated with the families having higher educational and income status. This agrees with the findings of this study that is children from small household size and low birth order exhibited better growth pattern as compared to those from larger household size and higher birth order.

Peck and Vagero, (1987) showed that children from larger families were shorter than those from small families. But some British studies showed that the family size-height relationship is not linearly correlated with growth (Silva et al., 1985). Studies by Silva et al. (1985) determined the effect of socio-economic factors and birth weight on growth of children and their result revealed that socio-economic status and birth weight were significantly correlated with stature, while the sex of children, maternal age, size of family, and ordinal position of the child in the family were not significantly related to each other. In general, height is a measure of beauty in humans which will affect the self-esteem of children in the 
future. Also weight is mark of health and deficiency of nutrient substance (Mohammadzadeh et al., 2010).

Belmont et al. (1975) in their study found that maternal education is associated with higher weight and height of children. The other significant factor which was observed in our children was economic status. The result indicated that weight and height of children are directly influenced by economic status. More welfare is a fertile field for growth. Eiben et al. (1996) evaluated the effect of socio-economic status on weight and height of children. Their results showed that people of high economic status were taller than those that had low economic status. They also observed that sons of senior salaried employee were taller than those of unskilled worker with about $2.9 \mathrm{~cm}$ (Eiben et al., 1996). Moreover, this study is in accord with other studies that have shown those of lower economic status have lower weight and height (Belmont et al., 1975).

Study by Thompson et al.(2002) showed that there is a wide variation among children in growth parameters at any given age and in the velocity of these parameters from one age to the next. This agrees with the findings of this study that showed variation in different anthropometric parameters in children at different ages.

\section{CONCLUSION}

The anthropometric parameters of growth examined in this study population showed that the males had higher height, weight, BMI, body circumferences than females. Conversely, females had higher values for biceps and triceps skin fold thickness than their male counterparts. Moreover, males had higher values of cephalofacial dimensions than the females. However, females showed higher nasal height than the males in this study, indicating cosmetic value that they are beautiful. In general, children from small family/household size show better growth than those of larger family/household size.

\section{REFERENCES}

Al-Sendi, A.M., Shetty, P. and Musaiger, A.O. (2003). Anthropometric and body composition indicators of Bahraini adolescents. Annals of Human Biology. 30(4): 367-379.

Ayodele, A. (2000). Kazaure emirate: Historical and social perspectives. More Blessing Printers, Kano. 1-22.

Banik, N.D.D., Ayar, S., Krishna, R. and Raj, L. (1972). The effect of nutrition on growth of pre-school children in different communities in Delhi. Indian Paediatrics. 9: 460-466.

Belmont, L., Stein, Z.A. and Susser, M.W. (1975). Comparison of associations of birth order with intelligence test score and height. Nature. 255(5503):54-56.

Berdasco, A. (1994). Body mass index values in the Cuban adult population. European Journal of Clinical Nutrition. 48:155-163.

Bolzan, A., Guimarey, L. and Frisancho, A.R. (1999). Study of growth in rural school children from Buenos Aires, Argentina using upper arm muscle area by height and other anthropometric dimensions of body composition. Annals of Human Biology. 26(2):185-193.

Bugaighis, I., Mattick, C.R., Bernard, T. and Ross, H. (2013). Three-dimensional gender differences in facial form of children in the North East of England. European Journal of Orthodontics, 35: 295-304.

Cameron, N. (1991). Human growth, nutrition, and health status in sub-Saharan Africa. Physical Anthropology. 34:211-250. 
Cameron, N., De Wet, T., Ellison, G.T. and Bogin, B. (1998). Growth in height and weight of South African urban infants from birth to five years: the birth to ten studies. American Journal of Human Biology. 10:495-504.

Donald, R.M. (2002). Gender and age differences in the relationship between body mass index and perceived weight: Exploring the paradox. International Journal of Men's Health. 1(1): 31-42.

Douglas, J.W. and Simpson, H.R. (1964). Height in relation to puberty, family size, and social class. The Milbank Memorial Fund Quarterly. 42:20-35.

Drachler, M.L., Bobak, M. and Rodrigues, L. (2002). The role of socio-economic circumstances in differences in height of preschool children within and between the Czech Republic and southern Brazil. Central Europe Journal of Public Health, 10:135141.

Eiben, O.G. and Mascie-Taylor, C.G.N. (2004). Children's growth and socio-economic status in Hungary. Economics and Human Biology. 21(2):295-320.

Eiben, O.G. and Pantó, E. (1988). Some data to growth of Hungarian youth in function of socio-economic factors. Anthropologies. 26: 19-23.

Eiben, O.G., Barabás, A., Kontra, G. and Pantó, E. (1996). Differences in growth and physical fitness of Hungarian urban and rural boys and girls. HOMO. 47(1-3):191-205.

Eleveth, P.B. andTanner, J.M. (1991). Worldwide variation in human growth. 2nd ed. Cambridge: Cambridge University Press. 34-38.

Ezekie, J., Anibeze, C.I.P., Uloneme, G.C. and Anyanwu, G.E. (2015). Height estimation of the Igbos using cephalo-facial anthropometry. International Journal of Current Microbiology and Applied Sciences. 4(6):305-316.

Fidanza, F. (1991). Anthropometric methodology. In Nutritional Assessment: a manual for population studies, edited by F. Fidanza. London: Chapman and Hall. 1-43.

Forsyth, S.J. (1982). Assessment of nutritional education: urban mother understanding of weight for age graphs. Papua New Guinea Medical Journal, 25:239-246.

Goldstein, H. (1971). Factors influencing the height of seven-year-old children. Results from the National Child Development Study. Human Biology. 43:92 - 111.

Ilayperuma, I. (2010). On the prediction of person s stature from cranial dimensions. International Journal of Morphology. 28(4): 1135-1140.

Kean, V. (2007). Assessment of growth," in Nelson Textbook of Pediatrics, R. Kliegman, R. Bhrman, H. B. Jenson, and B. F. Stanson, Eds., 18th edition, chapter 14, Saunders Elsevier, Philadelphia, USA. pp72.

Khalid, M.E.M., Mahmoud, M.S.W., Ahmed, M.E.K. and Adzaku, F.K. (1997). Fat indices in high and low altitude populations in Southern Saudi Arabia. Annals of Saudi Medicine. 17: 312-315.

Kharyal, A. and Nath, S. (2008). Estimation of stature from maxillo-facial measurements among Brahmins of Himachal Pradesh. Indian Journal of Forensic Odontology. 1(1):1316.

Kim, K.H., Spurgeon, J.H., French, K.E. and Kim, K.B. (2002). Somatic comparisons of South Korean children and youths born and reared in a rural area with the descendant $\mathrm{s}$ of rural to urban migrants. American Journal of Human Biology, 14:476-485.

Kpela, T., Danborno,B., Adebisi, S.S. and Ojo, S.A. (2016). Anthropometric study of cephalic index of adultTivand Idomaethnic groups of North central Nigeria. Global Advanced Research Journal of Medicine and Medical Sciences, 5(4):109-115.

Krishan, K. (2007). Individualizing characteristics of footprints in Gujjars of North India. Forensic Science International, 160(2-3):137-144. 
Kromeyer-Hauschild, K. and Jaeger, U. (2000). Growth studies in Jena, Germany: changes in sitting height, biacromial and bicristal breadth in the past Decenniums. American Journal of Human Biology, 12: 646-654.

Leatherman, T.L., Carey, J.W. and Thomas, R.B. (1995). Socio-economic change and patterns of growth in the Andes. American Journal of Physical Anthropology, 97:307-321.

Lohman, T.G., Roche, A.F. and Martorell, R. (1988). Anthropometric standardization reference manual. Champaign, Illinois: Human Kinetics Books. p1-11.

McGarvey, S.T. (1992). Economic modernization and human adaptability perspectives. In: Huss-Ashmore R, Schall R, Hediger M, editors. Health and lifestyle change. Philadelpha: University of Pennsylvania, 105-113.

Mohammadzadeh, A., Ahmadshah, F., Amiri, R. and Habibollah, E. (2010). Effect of birth weight and socioeconomic status on children's growth in Mashhad, Iran. International Journal of Paediatrics, 1-5.

Mozaffer, R.H., Masood ,A.Q. and Asghar, M. (2012). Neck circumference as a useful marker of obesity: a comparison with body mass index and waist circumference. Journal of Pakistan Medical Association. 62(1):36-40.

Naidu, A. and Rao, N. (1994). Body mass index: a measure of the nutritional status in Indian populations. European Journal of Clinical Nutrition. 48:131-140.

Olofin, A.E. (1987). Some aspect of physical geography of the Kano region and related human responses: Department Lecture Notes. 1: 14-20.

Olotu, J., Eroje, A., Oladipo, G. and Edibamode, E. (2009). Anthropometric study of the facial and nasal length of adult Igbo ethnic group in Nigeria. Internet Journal of Biological Anthropology, 2(2): 80-87.

Omotoso, D. R., Oludiran, O.O. and Sakpa, C. L. (2011). Nasofacial anthropometry of adult Bini tribe in Nigeria. African Journal of Biomedical Research, 14(3):219-221.

Patel, S. M., Shah, G.V. and Patel, S.V. (2007). Estimation of height from measurements of foot length in Gujarat region. Journal of Anatomical Society of India, 56(1): 1-6.

Peck, A.M. and Vågerö, D.H. (1987). Adult body height and childhood socioeconomic group in the Swedish population. Journal of Epidemiology and Community Health. 41(4):333337.

Pena-Reyes, M., Cardenas, B.E., Cahuich, M., Barragan, A. and Malina, R. (2002). Growth status of children 6-12 years from two different geographic regions of Mexico. Annals of Human Biology. 29 (1): 11 - 25.

Prasad, R., Kumar, R. and Dayal, R.S. (1971). Physical growth and development from 1 - 5 years. Indian Paediatrics. 8:105-120.

Roche, A.F. and Sun, S.S. (2003). Human Growth: Assessment and Interpretation, Cambridge University Press, Cambridge, UK. pp75-78.

Rona, R. and Chinn, S. (1986). National study of health and growth: social and biological factors associated with height of children from ethnic groups living in England. Annals of Human Biology. 5: 453-471.

Shah, T., Thaker, M. B. and Menon, S. K. (2015). Assessment of cephalic and facial indices: A proof for ethnic and sexual dimorphism. Journal of Forensic Science and Criminology, 3(1): 1-11.

Silva, P.A., Birkbeck, J. and Williams, S. (1985). Some factors influencing the stature of Dunedin 7-year-old children: a report from the Dunedin Multidisciplinary Health and Development Research Unit. Australian Paediatric Journal. 21(1): 27-30.

Tanner, J.M. (1994). Introduction: growth in height as a mirror of the standard of living, in Stature, Living Standards, and Economic Development, J. Komlos, Ed., The University of Chicago Press, London, UK. pp 1-6. 
Tracer, D.P., Sturt, R.J., Sturt, A. and Braithwaite, L.M. (1998). Two decade trends in birth weight and early childhood growth in Papua New Guinea. American Journal of Human Biology, 10:483-493.

Waterlow, J.C, Buzina, R. and Keller, W. (1977). The presentation and use of height and weight data for comparing the nutritional status of groups of children under the age of 10 years. Bulletin of World Health Organization, 55:489-498.

World Health Organisation. Working Group. (1986). Use and interpretation of anthropometric indicators of nutritional status. Bulletin of World Health Organization, 64:929-941. 